\title{
Editorial: Climate Change and Marine Top Predators
}

\author{
Morten Frederiksen ${ }^{1 *}$ and Tore Haug ${ }^{2}$ \\ ${ }^{1}$ Department of Bioscience, Aarhus University, Roskilde, Denmark, ${ }^{2}$ Institute of Marine Research, Tromsø, Norway
}

Keywords: climate, marine mammals, seabirds

Climate is one of the main structuring forces in natural ecosystems (Richardson and Schoeman, 2004), and anthropogenic climate change is regarded as an important driver of changes in the range and abundance of species as well as community composition, not least in marine ecosystems (Poloczanska et al., 2013). There are two overall mechanisms by which climate change can affect range and abundance of a species (Thomas, 2010): direct physiological effects, and indirect trophic effects mediated by other species. Understanding to what extent and through which mechanisms climate change affects particular species is one of the main challenges facing ecologists. In this collection of papers, researchers take a variety of approaches to the study of climate change impacts on marine birds and mammals, ranging from documentation of large-scale patterns, through quantification of impacts on vital rates, to detailed mechanistic studies of changing behavior, and physiological effects.

The first paper in this collection (Oro, 2014) describes the challenges involved in studying

\section{OPEN ACCESS}

Edited by:

Klaus D. Joehnk,

Commonwealth Scientific and Industrial Research Organisation,

Australia

Reviewed by:

Elvira S. Poloczanska,

Commonwealth Scientific and Industrial Research Organisation, Australia

*Correspondence: Morten Frederiksen mfr@bios.au.dk

Specialty section:

This article was submitted to Interdisciplinary Climate Studies,

a section of the journal

Frontiers in Ecology and Evolution

Received: 06 October 2015 Accepted: 19 November 2015 Published: 02 December 2015

Citation:

Frederiksen M and Haug T (2015) Editorial: Climate Change and Marine Top Predators.

Front. Ecol. Evol. 3:136. doi: $10.3389 /$ fevo.2015.00136 the impacts of climate change on seabirds, and critically evaluates the existing literature. One of the central issues identified in this paper is that reliance on single climate indices for describing changes in complex ecosystems may result in biased predictions. The remaining papers both illustrate some of these challenges, and contain pointers to ways in which they can be overcome.

Measuring climatic variation on a scale that makes sense in relation to the study organism is complex. In a cross-disciplinary paper, Mesquita et al. (2015) illustrate how methods from climatology can help identify ecologically meaningful covariates of population change, in this case of common guillemots (Uria aalge) in northern Norway. Distinguishing impacts of climate from other drivers is important and often difficult. Crawford et al. (2015) examine changes in distribution of several seabirds in South Africa, and conclude that reactions to fisheries dominate those to climate.

Most climate-related seabird studies have focused on the breeding colonies, while relatively few have examined changes in staging or wintering populations. Two papers examine respectively wintering alcids off Massachusetts (Veit and Manne, 2015) and staging shearwaters in the Bay of Biscay (Louzao et al., 2015). Both show species-dependent relationships between large-scale climate and the occurrence of seabirds in these areas.

Climate warming may both enhance poleward expansion of temperate species from lower latitudes and change the distribution of resident species at higher latitudes. This may present challenges both for newcomers and residents. Cod (Gadus morhua) abundance has increased, and its range has extended northwards in the Barents Sea in recent years. One implication of this is a new overlap of feeding grounds with harp seals (Pagophilus groenlandicus) and minke whales (Balaenoptera acutorostrata), two other important top predators in the area. Bogstad et al. (2015) demonstrate that both these mammal species have exhibited declines in body condition in recent years, and competition for food with the increasing cod stock is suggested as a possible explanation. Significant changes in the distribution and abundance of several cetacean species during recent decades has been shown both in Icelandic and adjacent waters (Víkingsson et al., 2015) and in the Norwegian Sea (Nøttestad et al., 2015). Both papers illustrate that whale species have the capability 
to rapidly perform shifts in distribution and abundance patterns strongly associated with adaptive search behavior in relation to both changing levels of abundance of their prey and increased sea surface temperatures.

Two papers investigate the impact of changes in sea ice on vital rates and population trends of Adélie penguins (Pygoscelis adeliae). One study documents complex long-term trophic effects (Ballerini et al., 2015), while the other shows strong impacts of stochastic events, viz. very large icebergs blocking access to foraging areas (Dugger et al., 2014). In both cases, the impacts on demography and population dynamics were profound.

Climate-related changes in demography as well as population and range dynamics are mediated by behavioral and physiological mechanisms. Two long-term studies on colonial birds illustrate the complexity of these links between climate, behavior and demography. In common terns (Sterna hirundo), Szostek et al. (2015) find that arrival date and mass at the breeding colony were related to climatic conditions and food availability in wintering and staging areas, but that age groups differed in their reaction to climate. Reed et al. (2015) show that the probability of skipping breeding in common guillemots was higher after warm winters, and that individuals differed in both mean skipping propensity and their response to temperature.

Behavioral reactions of one species to climatic change may lead to cascading effects on other species. Prop et al. (2015) show that the occurrence of polar bears (Ursus maritimus) on land during summer in Svalbard and Greenland has increased as sea ice cover has decreased, and that this has led to increased

\section{REFERENCES}

Ballerini, T., Tavecchia, G., Pezzo, F., Jenouvrier, S., and Olmastroni, S. (2015). Predicting responses of the Adélie penguin population of Edmonson Point to future sea ice changes in the Ross Sea. Front. Ecol. Evol. 3:8. doi: 10.3389/fevo. 2015.00008

Bogstad, B., Gjøsæter, H., Haug, T., and Lindstrøm, U. (2015). A review of the battle for food in the Barents Sea: Cod vs. marine mammals. Front. Ecol. Evol. 3:29. doi: 10.3389/fevo.2015. 00029

Crawford, R. J. M., Makhado, A. B., Whittington, P. A., Randall, R. M., Oosthuizen, W. H., and Waller, L. J. (2015). A changing distribution of seabirds in South Africa-the possible impact of climate and its consequences. Front. Ecol. Evol. 3:10. doi: 10.3389/fevo.2015. 00010

Dugger, K. M., Ballard, G., Ainley, D. G., Lyver, P. O. B., and Schine, C. (2014). Adélie penguins coping with environmental change: results from a natural experiment at the edge of their breeding range. Front. Ecol. Evol. 2:68. doi: 10.3389/fevo.2014.00068

Jenssen, B. M., Villanger, G. D., Gabrielsen, K. M., Bytingsvik, J., Bechshøft, T. Ø., Ciesielski, T. M., et al. (2015). Anthropogenic flank attack on polar bears: interacting consequences of climate warming and pollutant exposure. Front. Ecol. Evol. 3:16. doi: 10.3389/fevo.2015. 00016

Louzao, M., Afán, I., Santos, M., and Brereton, T. (2015). The role of climate and food availability on driving decadal abundance patterns of highly migratory pelagic predators in the Bay of Biscay. Front. Ecol. Evol. 3:90. doi: $10.3389 /$ fevo. 2015.00090 predation on ground-nesting colonial birds. Staying with polar bears, loss of sea ice, and reduced access to prey is likely to result in prolonged fasting periods with subsequent increases of tissue concentrations of persistent organic pollutants. In a perspective paper, Jenssen et al. (2015) suggest increased focus on potential population effects of such increases in pollutant exposure, and to consider such effects in addition to the effects of climate-induced habitat loss.

Overall, these papers illustrate the complexities both of the ways that climate change can impact marine top predators, and of the approaches taken to study this important subject. Research in this field is progressing rapidly, and innovative collaborations with neighboring disciplines are increasingly being used to good effect. Among the remaining challenges, the prediction of future changes in populations and communities still looms large, and success in this endeavor will depend on continual development of new collaborative approaches.

\section{AUTHOR CONTRIBUTIONS}

MF and TH co-wrote this editorial.

\section{ACKNOWLEDGMENTS}

We thank the authors of the papers included in this Research Topic for their excellent contributions, and the organizers of the ICES Annual Science Conference in 2014 for giving us the opportunity to put together an interesting set of talks, which later developed into this Research Topic.

Mesquita, M. d. S., Erikstad, K. E., Sandvik, H., Barrett, R. T., Reiertsen, T. K., Anker-Nilssen, T., et al. (2015). There is more to climate than the North Atlantic Oscillation: a new perspective from climate dynamics to explain the variability in population growth rates of a long-lived seabird. Front. Ecol. Evol. 3:43. doi: $10.3389 /$ fevo.2015.00043

Nøttestad, L., Krafft, B., Anthonypillai, V., Bernasconi, M., Langård, L., and Fernö, A. (2015). Observations of shifts in cetacean distribution in the Norwegian Sea. Front. Ecol. Evol. 2:83. doi: 10.3389/fevo.2014. 00083

Oro, D. (2014). Seabirds and climate: knowledge, pitfalls and opportunities. Front. Ecol. Evol. 2:79. doi: 10.3389/fevo.2014.00079

Poloczanska, E. S., Brown, C. J., Sydeman, W. J., Kiessling, W., Schoeman, D. S., Moore, P. J., et al. (2013). Global imprint of climate change on marine life. Nat. Clim. Change 3, 919-925. doi: 10.1038/nclimate1958

Prop, J., Aars, J., Bårdsen, B.-J., Hanssen, S. A., Bech, C., Bourgeon, S., et al. (2015). Climate change and the increasing impact of polar bears on bird populations. Front. Ecol. Evol. 3:33. doi: 10.3389/fevo.2015. 00033

Reed, T., Harris, M., and Wanless, S. (2015). Skipped breeding in common guillemots in a changing climate: restraint or constraint? Front. Ecol. Evol. 3:1. doi: 10.3389/fevo.2015.00001

Richardson, A. J., and Schoeman, D. S. (2004). Climate impacts on plankton ecosystems in the Northeast Atlantic. Science 305, 1609-1612. doi: 10.1126/science. 1100958

Szostek, K. L., Bouwhuis, S., and Becker, P. H. (2015). Are arrival date and body mass after spring migration influenced by large-scale environmental factors in a migratory seabird? Front. Ecol. Evol. 3:42. doi: 10.3389/fevo.2015. 00042 
Thomas, C. D. (2010). Climate, climate change and range boundaries. Divers. Distrib. 16, 488-495. doi: 10.1111/j.1472-4642.2010.00642.x

Veit, R. R., and Manne, L. L. (2015). Climate and changing winter distribution of alcids in the Northwest Atlantic. Front. Ecol. Evol. 3:38. doi: 10.3389/fevo.2015.00038

Víkingsson, G. A., Pike, D. G., Schleimer, A., Valdimarsson, H., Gunnlaugsson, T., Silva, T., et al. (2015). Distribution, abundance and feeding ecology of baleen whales in Icelandic waters: have recent environmental changes had an effect? Front. Ecol. Evol. 3:6. doi: 10.3389/fevo.2015. 00006
Conflict of Interest Statement: The authors declare that the research was conducted in the absence of any commercial or financial relationships that could be construed as a potential conflict of interest.

Copyright $\odot 2015$ Frederiksen and Haug. This is an open-access article distributed under the terms of the Creative Commons Attribution License (CC BY). The use, distribution or reproduction in other forums is permitted, provided the original author(s) or licensor are credited and that the original publication in this journal is cited, in accordance with accepted academic practice. No use, distribution or reproduction is permitted which does not comply with these terms. 